\title{
Хірургічне лікування гострокровоточивого раку правої половини ободової кишки
}

\author{
O. M. ANDRUSENKO \\ National Medical University by O. O. Bohomolets
}

\section{SURGICAL TREATMENT OF ACUTE BLEEDING CANCER OF THE RIGHT HALF OF THE COLON}

\begin{abstract}
Пацієнти з гострокровоточивим колоректальним раком, за даними нашої клініки, складають 21,6 \% в структурі кишкових кровотеч та 29,7 \% у структурі ускладненого колоректального раку. Об'єктом досліджень стали 58 хворих на гострокровоточивий рак правої половини ободової кишки, що були госпіталізовані в Київський міський центр для надання допомоги хворим із шлунково-кишковими кровотечами в період 2003-2014 рр. Операційне лікування проведено у 36 (62,1 \%) пацієнтів, серед яких у 31 (86,1 \%) - радикальне операційне втручання, паліативне та симптоматичне - у 5 (13,9\%). В екстреному порядку на висоті рецидиву кровотечі оперовано 2 (6,5 \%) пацієнти, обидва нерадикально, при цьому помер 1 (50,0 \%) хворий. У ранньому відстроченому періоді, після проведення адекватної підготовки та комплексного обстеження, операційне лікування виконано у 34 (93,5 \%) пацієнтів: радикально оперовано 31 (91,2 \%) та нерадикально - $3(8,8 \%)$, при цьому померлих після операційних втручань у ранньому відстроченому періоді не було. Загальна післяопераційна летальність склала 2,8 \% (1 хворий), при цьому питома вага летальності після нерадикальних операційних втручань склала 20,0 \%, на противагу показнику летальності після радикальних операцій, який дорівнює 0. Летальних випадків після операційних втручань, проведених у ранньому відстроченому періоді, не було порівняно з летальністю після екстрених операцій, яка склала 50,0% (1 випадок із 2).

Patients with acute bleeding colorectal cancer according to our clinic constitute $21.6 \%$ of the intestinal bleeding and $29.7 \%$ in the structure of complicated colorectal cancer. The object of the study were 58 patients with acute bleeding cancer of the right half of the colon hospitalized in Kyiv City Center to provide care for patients with gastrointestinal bleeding during the 2003-2014 years. Surgical treatment was performed in 36 (62.1 \%) patients, 31 of whom (86.1 \%) with radical surgical interventions, palliative and symptomatic - $5(13.9 \%)$. As amatter of urgencyat the height of rebleeding operations were $2(6.5 \%)$ patients, both non-radicals, while died $1(50.0 \%)$ patient. In early delayed period, after adequate preparation and diligence surgery was performed in 34 $(93.5 \%)$ patients: radically operated $31(91.2 \%)$, and non-radically $-3(8.8 \%)$, with no patient deaths after surgery in the EDP. The overall postoperative mortality was $2.8 \%$ (1 patient), while the proportionof mortality after non-radical surgery was $20.0 \%$, in contrast to mortality rates after radical surgery, which is 0 . Deathsafter surgery, conducted in early delay time, there was no comparison with mortality after emergency operations, which amounted to $50.0 \%$ (1 case among 2).
\end{abstract}

Постановка проблеми і аналіз останніх досліджень та публікацій. Хірургія колоректального раку зробила великий крок від першої колостомії, яку виконав Fine у 1797 р., до тотальної мезоректумектомії, запропонованої Bill Heald у 1982 р. та тотальної мезоколонектомії, автором якої став Hogenberger у 2009 р. [5, 6]. Удосконалена техніка операційного втручання у поєднанні 3 сучасними високоточними технологіями суттєво полегшила роботу хірургів, але й досі питання діагностики та лікування колоректального раку залишається актуальним [3, 7, 8, 9].

За даними Міжнародного агентства 3 дослідження онкологічних захворювань IARC, що входить до складу ВООЗ, у 2012 р. в світі зареєст- ровано 1,36 млн нових випадків захворювання на колоректальний рак (КРР), з них в Об'єднаній Європі - 345 тис., у США - 134 тис. Померли у 2012 р. в усьому світі - 694 тис. хворих на КРР, з них в Об'єднаній Європі - 152 тис., в США - 55 тис. За даними нашої клініки, пацієнти з гострокровоточивим колоректальним раком складають 21,6 \% у структурі кишкових кровотеч та 29,7 \% у структурі ускладненого колоректального раку.

Підсумувавши досвід лікування хворих із кишковими кровотечами, в тому числі пухлинного походження, в клініці розроблено та впроваджено у практичну діяльність активно-очікувальну тактику лікування хворих, що полягає у визначенні показань, термінів проведення та вибору способу опе- 
раційного втручання залежно від загального стану хворого, активності та тяжкості кровотечі, стану гемостазу в морфологічному субстраті кровотечі, віку хворого та індексу поліморбідності.

Головним методом лікування раку правої половини ободової кишки був та залишається хірургічний, а у випадку ускладнення перебігу злоякісного пухлинного процесу розвитком кровотечі хірургічний метод $є$ ще й методом здійснення остаточного гемостазу [1, 2, 4].

Мета роботи: покращення результатів хірургічного лікування гострокровоточивих злоякісних пухлин правої половини ободової кишки.

Матеріали і методи. Об’єктом досліджень стали 58 хворих на гострокровоточивий рак правої половини ободової кишки, які були госпіталізовані в Київський міський центр для надання допомоги хворим із шлунково-кишковими кровотечами в період 2003-2014 рр. Виявлено гострокровоточивий рак таких локалізацій: сліпа кишка - 24 (41,3 \%), висхідна ободова 16 (27,6 \%), печінковий згин - 11 (19,0 \%), права половина поперечної ободової кишки - 7 (12,1 \%). Вік госпіталізованих хворих коливався від 41 до 85 років. Чоловіків - 28 (48,3 \%), вік у межах від 41 до 85 років, середній вік $(64,6 \pm 10,6)$ року. Жінок - 30 (51,7 \%), вік у межах від 50 до 89 років, середній вік $(69,1 \pm 9,8)$ року. Осіб похилого та старечого віку - 86,2 \%.

У всіх пацієнтів мали місце супутні захворювання різних органів та систем, що характерно для цієї вікової категорії хворих (поліморбідність 100 \%). Індекс поліморбідності склав 4,7 у чоловіків та 5,3 - у жінок. У 9 (15,5 \%) хворих діагноз вже встановлено раніше в інших медичних закладах. Вперше колоректальний рак виявлено в нашій клініці у 49 (84,5 \%) хворих.

Згідно з Міжнародною класифікацією злоякісних новоутворень $\mathrm{TNM}-7^{\text {th }} \mathrm{ed}$, серед госпіталізованих хворих встановлено такі стадії злоякісного процесу: I стадія - у 2 (3,4 \%) хворих, II стадія - у 33 (56,9 \%), III стадія - у 12 (20,7\%), IV стадія - у 11 (19,0 \%). Згідно з прийнятою в клініці класифікацією тяжкості шлунково-кишкових кровотеч (В. Д. Братусь, 2001 р.), помірний ступінь тяжкості геморагії був у 13 (22,4 \%), середній у 10 (17,3 \%), тяжкий - у 35 (60,3 \%) пацієнтів. Співвідношення тяжкості кровотечі: помірна/ середня/тяжка - 1,0/0,5/0,9.

Результати досліджень та їх обговорення. Згідно з визначеними показаннями операційне лікування проведено у 36 (62,1 \%) пацієнтів, серед яких у 31 (86,1%) радикальне операційне втручан- ня, паліативне та симптоматичне - у 5 (13,9 \%). У групі хворих із вперше виявленим раком правої половини ободової кишки операційна активність склала 65,3 \% (32 із 49). Радикальні операції було виконано в таких стадіях пухлинного процесу: I стадія - 2 (6,5 \%), II - 19 (61,3 \%), III - 9 (29,0 \%), IV - 1 (3,2 \%). При місцевому поширенні раку ободової кишки на інші органи черевної порожнини проведено комбіновані операційні втручання у 3 (8,3%) пацієнтів. Додатково виконано: крайову резекцію печінки - у 2 (66,7 \%) хворих, резекцію тонкої кишки - у 1 (33,3 \%) пацієнта. Симультанних операційних втручань виконано 3 (8,3 \%), у всіх випадках - холецистектомію.

Паліативні (циторедуктивні) операційні втручання були виконані з метою видалення первинної пухлини для забезпечення надійного хірургічного гемостазу при наявності відповідного біологічного ресурсу пацієнта. За таких умов паліативне операційне втручання $є$ методом здійснення кінцевого хірургічного гемостазу, зменшує питому вагу непластичної тканинної маси, що, в свою чергу, зменшує інтенсивність ракової інтоксикації та процеси метастатичного розповсюдження злоякісного пухлинного процесу, суттєво підвищує ефективність проведеної у післяопераційному періоді хіміо- та променевої терапії та створює сприятливі умови для компенсації анемії і відновлення процесів білкового й азотистого обміну. Нерадикальних (паліативних та симптоматичних) операційних втручань виконано 5 (13,9\%).

Консервативну терапію отримували 22 (37,9 \%) хворих, серед яких відмовились від операційного лікування 9 (40,9 \%) пацієнтів, діагностовано розповсюджені та генералізовані форми раку, що визначали неоперабельність пухлинного процесу в 6 (27,3 \%) хворих, операцію визнано непереносимою внаслідок наявності тяжкої соматичної патології у 7 (31,8 \%) пацієнтів.

Для передопераційного очищення товстої кишки застосовували ті ж методики, які використовують для підготовки кишечника до ендоскопічного дослідження, а саме: приймання осмотичних проносних або за допомогою сифонних клізм. При явищах параканкрозу проводили передопераційну деконтамінацію товстої кишки комбінацією препаратів фторхінолонового ряду та похідних імідазолу. Якісна підготовка кишечника знижує ризик розвитку післяопераційних ускладнень та сприяє швидшому відновленню перистальтики, що покращує перебіг раннього післяопераційного періоду.

Коли операційне втручання виконали 3 приводу гострої кишкової кровотечі з явищами кишкової непрохідності на тлі стенозувальної пухлини, здій- 
снювали інтраопераційне екстракорпоральне очищення кишечника.

Об’єм операційного втручання залежав від локалізації та розповсюдженості ракового процесу (місцеве розповсюдження, метастази в регіонарні лімфатичні вузли, розповсюдження по очеревині, віддалені метастази), від загального стану хворого, активності та тяжкості кровотечі, стану гемостазу в морфологічному субстраті кровотечі, віку хворого та індексу поліморбідності. Об’єм операційного втручання є основним лікувальним фактором, що визначає прогноз захворювання.

У роботі дотримувались критеріїв абластичності операційних втручань:

1. Виключення механічної дії на злоякісну пухлину - don't touch operation.

2. Рання перев’язка та пересічення магістральних судин (медіально-латеральна мобілізація).

3. Перев'язка кишки не менш ніж на 5-7 см вище та нижче пухлини до її мобілізації для ліквідації імплантаційного внутрішньопросвітного та підслизового лімфатичного розповсюдження злоякісних клітин.

4. Видалення пухлини єдиним блоком з регіонарним лімфатичним апаратом (мезоректумектомія, мезоколонектомія).

5. Зміна рукавичок та інструментів за ходом операції.

6. Багатократне поточне промивання черевної порожнини антисептиками.

7. Використання сучасних хірургічних технологій у ході мобілізації та лімфодисекції (ультразвуковий скальпель Harmonic, електрозварювальні апарати типу LigaSure, EnSeal та EK300MI, електрохірургічні імпульсні генератори).

Обов'язково в протоколі операційного втручання вказували: локалізацію пухлини, її розміри, морфологічну форму, глибину інвазії, проростання в інші органи та тканини, відстань до краю резекції, кількість змінених та видалених лімфатичних вузлів, фонові захворювання кишечника.

У таблиці 1 наведено показники хірургічної активності та післяопераційної летальності залежно від умов проведення операцій.
Із наведених даних встановлено, що в екстреному порядку (ЕП) на висоті рецидиву кровотечоперовано 2 (5,6 \%) пацієнти, обидва нерадикально, при цьому помер 1 (50,0 \%) пацієнт.

У ранньому відстроченому періоді, після проведення адекватної підготовки та комплексного обстеження, операційне лікування проведено у 34 (93,5 \%) хворих: радикально оперовано 31 (91,2 \%), та нерадикально - 3 (8,8 \%), при цьому померлих після операційних втручань у ранньому відстроченому періоді не було.

Загальна післяопераційна летальність склала 2,8 \% (1 хворий), при цьому питома вага летальності після нерадикальних операційних втручань склала 20,0 \%, на противагу показнику летальності після радикальних операцій, який дорівнює 0. Летальних випадків після операційних втручань, проведених у ранньому відстроченому періоді, не було, порівняно з летальністю після екстрених операцій, яка склала 50,0 \% (1 випадок із 2).

Загалом виконано 31 (86,1 \%) радикальне операційне втручання, а саме: правобічну геміколектомію - 30 (96,8 \%), резекцію поперечної ободової кишки - 1 (3,2 \%). Всі радикальні операційні втручання виконано в ранньому відстроченому періоді (100 \%). Після радикальних операційних втручань летальних випадків не було.

Нерадикальні операції виконано у 5 (13,9 \%) хворих: паліативну правобічну геміколектомію у 3 (60,0 \%) пацієнтів, експлоративну лапаротомію - у 2 (40,0 \%) осіб.

Із 5 нерадикально оперованих хворих 2 (40,0 \%) оперовано в екстреному порядку на висоті рецидиву кровотечі, а 3 (60,0 \%) - у ранньому відстроченому періоді. Після нерадикальних екстрених операційних втручань помер 1 (50,0 \%) хворий. Після нерадикальних операційних втручань у ранньому відстроченому періоді померлих не було. Загальна летальність після нерадикальних операцій становить 20,0 \% (1 хворий), на противагу показнику летальності після радикальних операційних втручань, який дорівнює 0. Паліативні операції доповнені проведенням алкоголізації метастазів у пе-

Таблиця 1. Показники хірургічної активності та післяопераційної летальності залежно від умов проведення операцій

\begin{tabular}{||l|c|c|c||}
\hline \hline Умови проведення операцій & Радикальні (\%) & Нерадикальні (\%) & Усього (\%) \\
\hline Екстрені операції & - & $2(100)$ & $2(5,6)$ \\
\hline Померли & - & $1(50)$ & $1(50,0)$ \\
\hline Ранньо-відстрочені операції & $31(91,2)$ & $3(8,8)$ & $34(94,4)$ \\
\hline Померли & - & $5(13,9)$ & - \\
\hline Усього операцій & $31(86,1 \%)$ & $1(20,0)$ & $36(100)$ \\
\hline Померли (питома вага) & - & $(2,8)$ \\
\hline \hline
\end{tabular}




\section{З ДОСВІДУ РОБОТИ}

чінку в 1 (33,3 \%) хворого та фенестрацією парієтальної очеревини в 1 (33,3 \%) пацієнта.

Лімфодисекцію в об'ємі D1 виконано при проведенні 3 (9,7 \%) радикальних операційних втручань, всі - правобічна геміколектомія, лімфодисекція в об'ємі D2 - 28 (90,3 \%): правобічна геміколектомія - 27 (96,4 \%), резекція поперечної ободової кишки - 1 (3,6 \%). Серед хворих, у яких виконано лімфодисекцію, оперованих в екстреному порядку не було, всі оперовані у ранньому відстроченому періоді. Загалом лімфодисекцію D2 виконано у переважної кількості пацієнтів, що перевищує кількість лімфодисекції D1 у 9,3 раза.

Передумовою проведення радикального операційного втручання $є$ його виконання у ранньому відстроченому періоді, тому що при екстреному операційному втручанні на висоті кровотечі або при рецидиві кровотечі у хворих з геморагічним шоком та нестабільною гемодинамікою хірург зосереджений на видаленні пухлини з метою здійснення остаточного гемостазу та врятування життя хворого.

Тому забезпечення надійного гемостазу в постгеморагічному періоді на тлі клініко-моніторин-

\section{СПИСОК ЛІТЕРАТУРИ}

1. Антипова С. В. Алгоритм и методы хирургического лечения осложненных форм колоректального рака / С. В. Антипова Е. В. Калинин, В. В. Шляхтин // Онкология. - 2009. № 4. - С. 293-297.

2. Белозьоров І. В. Тактика лікування колоректального раку, що ускладнений кровотечею / I. В. Белозьоров // Харків. хірург. школа. - 2013. - № 3. - С. 142-143.

3. Интенсивная послеоперационная терапия больных колоректальным раком, осложненным кровотечением / В. В. Бойко, И. В. Белозеров, В. Г. Грома [и др.] // Медицина сьогодні і завтра. - 2010. - № 2/3. - С. 189-194.

4. Смирнов М. Л. Хірургічна тактика у хворих на гострокровоточиві пухлини травного каналу : автореф. дис. на здобуття наук. ступеня канд. мед. наук : 14.01 .03 / Смирнов Микола Леонідович ; Харк. держ. мед. університет. - Х., 2007. -22 c.

5. Complete mesocolic excision with central vascular ligation produces an oncologically superior specimen compared with stan- гових процедур є необхідним для проведення операційного втручання у ранньому відстроченому періоді.

Висновки. 1. Летальність після екстрених операційних втручань складає 50,0 \% (1 випадок із 2) порівняно з операціями, що виконані у ранньому відстроченому періоді після проведення адекватної передопераційної підготовки, при яких летальних випадків не спостерігали.

2. Летальність після нерадикальних операційних втручань склала 20,0 \% на противагу показнику летальності після радикальних операцій, який дорівнює 0.

3. Забезпечення надійного гемостазу та гладкого перебігу постгеморагічного періоду дозволяє оперувати хворих у ранньому відстроченому періоді, що є доцільним з точки зору зменшення ризику для життя хворого і можливості виконання радикальних операційних втручань з лімфодисекцією в об’ємі D2, як показали наші дослідження, у 90,3 \% хворих з гострокровоточивим раком правої половини ободової кишки.

dard surgery for carcinoma of the colon / N. P. West, W. Hohenberger, K. Weber [et al.] // J. Clin. Oncol. - 2010. - Vol. 28, № 2. - P. 272-278.

6. García-Granero E. [Assessment of the quality of bowel cancer surgery: "from the mesorectum to the mesocolon"] : [article in Spanish] / E. García-Granero // Cir. Esp. - 2010. - Vol. 87, № 3. - P. 131-132.

7. Gordon P. H. Principles and practice of surgery of colon, rectum, and anus / P. H. Gordon, S. Nivatvongs. - 3rd ed. New York: InformaHealthcare, 2006. - 1360 p.

8. Insufficient lymph node dissection is an independent risk factor for postoperative cancer death in patients undergoing surgery for stage II colorectal cancer / M. Ishizuka, H. Nagata, K. Takagi, K. Kubota // Eur. Surg. Res. - 2011. -Vol. 46, № 2. - P. 57-64. 9. Medially approached radical lymph node dissection along the surgical trunk for advanced right-sided colon cancers / S. Hasegawa, J. Kawamura, S. Nagayama [et al.] // Surg. Endosc. - 2007. Vol. 21, № 9. - P. 1657. 